\title{
IMPLEMENTASI KETERBUKAAN INFORMASI PUBLIK DI KABUPATEN SLEMAN
}

\author{
Arief Hartanto \\ Staf Ahli FPAN DPRD Sleman \\ stafahlifraksipan.dprds/eman@gmail.com
}

\begin{abstract}
Abstrak
Terbitnya UU No 14 Tahun 2008 tentang Keterbukaan Informasi Publik (UU KIP) yang berlaku efektif sejak 2010 lalu perlu diikuti dengan langkah-langkah implementatif pada badan-badan publik sebagaimana diatur ole $h$ undang-undang ini. Peran pemerintah daerah, implementasi UUI KIP perlu dilakukan untuk tidaksekadar memberikan informasi, melakukan diseminasi informasi dan penjaringan aspirasi masyarakat; melainkan juga mampu mengedukasi publik, untuk terwujudnya kondisi yang kondusif bagipelaksanaan pembangunan daerah dan peningkatan kesejahteraan masyarakat. Tulisan ini mencoba memaparkan implementasi UU KIP yang telah dilakukan Pemerintah daerah Kabupaten Sleman, yang hasilnya telah membuahkan penghargaan nasional pada tahun 2012.
\end{abstract}

Keywords: Keterbukaan Informasi Publik, Badan Publik, Pemerintah Daerah, PPID, SKPD, Diseminasi informasi

\section{PENDAHULUAN}

Salah satu tema penting dalam perbincangan demokratisasi di Indonesia adalah keterbukaan informasi publik. Tujuan utama keterbukaan informasi di setiap negara adalah memastikan bahwa lembaga publik akan lebih akuntabel dan kredibel dengan menyediakan informasi dan dokumen sesuai permintaan publik. Menurut Purwoko (2004) demokrasi tidak hanya dipahami sebagai enam elemen seperti adaya pejabat yang dipilih; pemilu yang bebas, adil dan berkala, kebebasan berpendapat; akses sumber-sumber informasi alternatif; otonomi asosional; dan hak kewarganegaraan. Lebih dari itu demokrasi adalah adalah kesempatan bagi semua pihak untuk terlibat dalam pengambilan keputusan bersama.

Disinilah hak untuk memperoleh informasi publik merupakan hak asasi manusia sebagaimana tercantum dalam konsideran Undang-Undang No 14 Tahun 2008 tentang Keterbukaan Informasi Publik (UU KIP). Pemerintahan yang terbentuk dari proses demokrasi menurut Amien Rais ( 2004 ) hendaknya mengutamakan kepentingan rakyat kecil, kepentingan dan kehiduan kaum buruh, tani, nelayan dan pegawai-pegawai kecil dan jangan sampai yang terjadi justru bahwa keenyataan riil bersebrangan dengan pernyataan-pernyataan pemerintah.

UU KIP mewajibkan seluruh badan publik untuk dapat mengelola informasi publik. Pengelolaan informasi publik tersebut dimaksudkan agar mudah diakses oleh masyarakat. Dengan prinsip keterbukaan informasi terhadap masyarakat itu, diharapkan dapat mewujudkan penyelenggaraan negara yang baik, transparan, efektif dan efisien, akuntabel serta dapat dipertanggung jawabkan. 
UU KIP memberi hak kepada setiap orang untuk memperoleh informasi dengan mengakses data yang ada di badan publik, dan menegaskan bahwa setiap informasi publik itu harus bersifat terbuka dan dapat diakses oleh setiap pengguna informasi publik, selain dari informasi yang dikecualikan yang diatur oleh Undang-Undang ini. Undang-Undang ini mengisyaratkan adanya jaminan kepada setiap individu atau kelompok masyarakat atau badan publik lainnya untuk memperoleh informasi yang diinginkan dan dapat digunakan untuk kepentingan sendiri atau publikasi.

Regulasi yang berkaitan dengan kebebasan informasi atau lebih dikenal keterbukaan informasi publik di Indonesia akan selalu memuat hak setiap orang untuk memperoleh informasi, kewajiban badan publik menyediakan dan melayani permintaan informasi secara cepat dan tepat waktu, biaya ringan (proporsional), dan cara sederhana, adanya pengecualian informasi bersifat ketat dan terbatas, serta kewajiban badan publik untuk membenahi sistem dokumentasi dan pelayanan informasi.

Kasim ( 2009 ) menyebutkan bahwa secara fundamental, sebuah informasi adalah milik publik, bukan milik pemerintah atau badan publik. Akan tetapi pemerintah memang harus menjaga keseimbangan antara menutup informasi dan kepentingan publik. Namun, bagaimanapun, kepentingan publik tetap harus didahulukan.

Padadasarnyaketerbukaanbukanhalasing dalamliteraturdan referensipenyelenggaraan birokrasi di Indonesia. Di awal tahun 1990-an pernah berkembang konsep good governance sebagai mekanisme pengelolaan sumber daya ekonomi dan sosial yang melibatkan pengaruh negara dan non-pemerintah dalam suatu usaha kolektif.

Penegasan atas hak atas informasi dinyatakan dalam UU No. 39/1999 tentang HAM. Di dalam Pasal 14 dinyatakan bahwa setiap orang berhak untuk mencari, memperoleh, memiliki, menyimpan, mengolah, dan menyampaikan informasi dengan menggunakan segala jenis sarana yang tersedia. Hak ini diperlukan untuk mengembangkan pribadi dan lingkungan sosial.

Di samping itu diskusi yang tidak kalah pentingnya pada pertemuan Bakohumas tersebut adalah tentang pelaksanaan UU No. 14 Tahun 2008 tentang Keterbukaan Informasi Publik (KIP), khususnya pasal 13 tentang kewajiban Badan Publik menunjuk Pejabat Pengelola Informasi dan Dokumentasi (PPID). Dalam era keterbukaan informasi seperti sekarang ini, keberadaan PPID sangat penting dan diperlukan oleh Badan Publik, karena PPID yang bertanggungjawab dalam penyediaan, penyimpanan, pendokumentasian, dan pengamanan informasi serta memberikan pelayanan informasi kepada masyarakat yang membutuhkan.

Subadi ( 2011 ) mengutip data Dirjen Informasi dan Komunikasi Publik, Kemenkominfo, sampai saat ini, secara rata-rata baru $21,21 \%$ Lembaga Publik yang menunjuk PPID, dengan rincian sebagai berikut :

\begin{tabular}{|c|c|c|c|c|}
\hline No. & Lembaga & Jumlah & PPID & $\%$ \\
\hline 1. & Kementerian & 34 & 27 & $79,41 \%$ \\
\hline 2. & LPNK & 129 & 32 & $24,81 \%$ \\
\hline 3. & Provinsi & 33 & 15 & $45,45 \%$ \\
\hline 4. & Kabupaten & 399 & 55 & $13,37 \%$ \\
\hline 5. & Kota & 98 & 18 & $18,37 \%$ \\
\hline & Jumlah & $\mathbf{6 9 3}$ & $\mathbf{1 4 7}$ & $\mathbf{2 1 , 2 1} \%$ \\
\hline
\end{tabular}

Informasi Publik adalah informasi yang dihasilkan, disimpan, dikelola, dikirim, dan/atau diterima oleh suatu badan publik yang berkaitan dengan penyelenggara dan penyelenggaraan 
negara dan/atau penyelenggara dan penyelenggaraan badan publik lainnya yang sesuai dengan Undang-Undang ini serta informasi lain yang berkaitan dengan kepentingan publik. Terdapat beberapa jenis informasi publik yang diatur dalam regulasi tersebut di antaranya: (1) informasi yang wajib disediakan dan diumumkan secara berkala, (2) informasi yang wajib diumumkan secara serta merta, (3) informasi yang wajib tersedia setiap saat dan (4) informasi yang dikecualikan.

Sedangkan pengertian Badan Publik adalah lembaga eksekutif, legislatif, yudikatif, dan badan lain yang fungsi dan tugas pokoknya berkaitan dengan penyelenggaraan negara, yang sebagian atau seluruh dananya bersumber dari Anggaran Pendapatan dan Belanja Negara dan/atau Anggaran Pendapatan dan Belanja Daerah, atau organisasi non pemerintah sepanjang sebagian atau seluruh dananya bersumber dari Anggaran Pendapatan dan Belanja Negara dan/atau Anggaran Pendapatan dan Belanja Daerah, sumbangan masyarakat dan/ atau luar negeri.

Adapun Informasi Publik yang wajib disediakan setiap saat oleh Badan Publik sesuai pasal 11 diantaranya adalah :

1. Daftar seluruh Informasi Publik yang berada di bawah penguasaannya, tidak termasuk informasi yang dikecualikan.

2. Hasil keputusan Badan Publik dan pertimbangannya;

3. Seluruh kebijakan yang ada berikut dokumen pendukungnya;

4. Rencana kerja proyek termasuk di dalamnya perkiraan pengeluaran tahunan Badan Publik;

5. Perjanjian Badan Publik dengan pihak ketiga;

6. Informasi dan kebijakan yang disampaikan Pejabat Publik dalam pertemuan yang terbuka untuk umum;

7. Prosedur kerja pegawai Badan Publik yang berkaitan dengan pelayanan masyarakat; dan/ atau;

8. Laporan mengenai pelayanan akses Informasi Publik yang sebagaimana diatur dalam undang-undang ini.

Selain itu masih ada juga Informasi Publik yang wajib disediakan dan diumumkan secara berkala oleh Badan Publik diantaranya, yang berkaitan dengan Badan Publik, kegiatan dan kinerja Badan Publik, laporan keuangan dan/atau informasi lain yang diatur dalam peraturan perundangan.

Keterbukaan informasi yang berkembang dan kebutuhan informasi publik yang meluas akan mendorong semakin banyak lagi masyarakat yang memanfaatkan haknya untuk meminta informasi publik yang ingin diketahuinya. Tentu saja hal ini tidak bisa dianggap remeh oleh Badan Publik karena sesuai ketentuan, permohonan masyarakat wajib dilayani bahkan dalam waktu yang sudah ditetapkan yaitu 10 hari kerja sejak diterimanya permintaan (Pasal 22 ayat 7), meskipun dapat diperpanjang paling lambat 7 hari kerja (Pasal 22 ayat 8 ).

Terkait dengan pelaksanaan UU 14 tahun 2008 pada 20 Agustus 2010 terbitlah PP 61 tahun 2010 (diundangkan 23 Agustus 2010). Hal yang penting diatur yaitu terkait PPID (Pejabat Pengelola Informasi dan Dokumentasi), yaitu pejabat yang bertanggung jawab di bidang penyimpanan, pendokumentasian, penyediaan, dan / atau pelayanan informasi di badan publik sebagaimana dikemukan oleh Agus Indarto ( 2011 ). 
Termaktub di antaranya dalam Pasal 12 ayat (1) Pejabat yang dapat ditunjuk sebagai PPID di lingkungan Badan Publik Negara yang berada di pusat dan di daerah merupakan pejabat yang membidangi Informasi Publik. Ayat (2) PPID sebagaimana dimaksud pada ayat (1) ditunjuk oleh pimpinan setiap Badan Publik Negara yang bersangkutan. Ayat (3) PPID di lingkungan Badan Publik selain Badan Publik Negara ditunjuk oleh pimpinan Badan Publik yang bersangkutan.

Pasal 21 PP tersebut juga amanatkan PPID harus sudah ditunjuk paling lama 1 (satu) tahun terhitung sejak Peraturan Pemerintah ini diundangkan (Pasal 21 ayat 1) berarti tanggal 23 Agustus 2011.Dalam hal PPID belum ditunjuk, tugas dan tanggung jawab PPID dapat dilakukan oleh unit atau dinas di bidang informasi, komunikasi, dan/atau kehumasan (pasal 21 ayat (2)).

Khusus terkait Badan Publik Negara dalam hal ini Pemda, Mendagri pada 14 Mei 2010 telah mengeluarkan Permendagri 35 tahun 2010 tentang Pedoman Pengelolaan Pelayanan Informasi dan Dokumentasi di lingkungan Kementerian Dalam Negeri dan Pemda. Khusus untuk pemerintahan Kabupaten, PPID ditetapkan oleh Bupati (Pasal 7 ayat 5) dan dibantu oleh PPID Pembantu yang berada di lingkungan SKPD(Satuan Kerja Perangkat Daerah) dan atau Pejabat Fungsional (Pasal 8 ayat 6 ). Sedangkan tata kerja PPID di lingkungan Pemkab diatur dalam Peraturan Bupati (Pasal 12 ayat (3)).

\section{PELAJARAN KETERBUKAAN INFORMASI PUBLIK DARI KABUPATEN SLEMAN}

Kabupaten Sleman dengan jumlah penduduk pada tahun 2011 tercatat sebanyak 1.125.369 jiwa. Penduduk laki-laki berjumlah 559.302 jiwa (49,70\%), perempuan 566.067 jiwa $(50,30 \%)$ dengan pertumbuhan penduduk sebesar $0,73 \%$ dengan jumlah Kepala Keluarga sebanyak 305.376

Penduduk Kabupaten Sleman sebagian besar berada pada rentang usia produktif 1560 tahun. Struktur penduduk Kabupaten Sleman tahun 2011 menurut data yang diperoleh dari website resmi Kabupaten Sleman terlihat dalam tabel berikut:

Struktur Penduduk Kabupaten Sleman Tahun 2011

\begin{tabular}{|c|c|c|c|c|}
\hline No & Usia (th) & Laki-laki & Perempuan & Total \\
\hline 1. & $0-4$ & 32.088 & 30.285 & 62.373 \\
\hline 2. & $5-9$ & 38.799 & 36.371 & 75.170 \\
\hline 3. & $10-14$ & 40.252 & 37.453 & 77.705 \\
\hline 4. & $15-19$ & 37.461 & 35.289 & 72.750 \\
\hline 5. & $20-24$ & 37.095 & 36.334 & 73.429 \\
\hline 6. & $25-29$ & 49.703 & 50.034 & 99.737 \\
\hline 7. & $30-34$ & 55.938 & 54.872 & 110.810 \\
\hline 8. & $35-39$ & 51.435 & 51.699 & 103.134 \\
\hline 9. & $40-44$ & 48.386 & 48.432 & 96.818 \\
\hline 10. & $45-49$ & 39.475 & 40.390 & 79.865 \\
\hline 11. & $50-54$ & 32.822 & 34.389 & 67.211 \\
\hline 12. & $55-59$ & 26.945 & 26.944 & 53.889 \\
\hline 13. & $60-64$ & 17.862 & 19.636 & 37.498 \\
\hline 14. & $65-69$ & 16.253 & 18.349 & 34.602 \\
\hline 15. & $70-74$ & 13.219 & 16.037 & 29.256 \\
\hline 16. & 75 ke atas & 21.569 & 29.553 & 51.122 \\
\hline & Total & 559.302 & 566.067 & 1.125 .369 \\
\hline
\end{tabular}


Pemkab Sleman juga mengupayakan transparansi penyelenggaraan pemerintahan sesuai yang dimaksud dalam UU No. 14 Tahun 2008 tentang Keterbukaan Informasi Publik. Sebagaimana dikutip dari website resmi Pemda Sleman bahwa implementasi hal ini dikelola langsung oleh Bagian Humas Setda Sleman yang bertugas merumuskan kebijakan dalam mewujudkan jalinan komunikasi antara Pemkab Sleman dengan masyarakat serta menjadi pintu informasi kebijakan publik kepada masyarakat. Saat ini, Bagian Humas juga melaksanakan tugas sebagai PPID, sesuai dengan amanah UU Keterbukaan Informasi Publik. Pemkab Sleman tidak membentuk PPID, karena fungsi PPID telah dijalankan oleh bagian Humas. Saat ini Pemkab sedang menyelesaikan SOP pelayanan informasi publik.

Berbagai informasi terkait pemerintahan di Kabupaten Sleman dapat diakses dengan relatif mudah di http: www.slemankab.go.id. Website tersebut dapat memberikan gambaran tentang Sleman melalui berbagai informasi yang disajikan dengan interaktif. Selain itu berbagai aspek pembangunan juga dapat diakses disitus tersebut seperti:

1. Kondisi Fisik dan Infrastruktur: Pengendalian Pertanahan Daerah, Geografis, Karakteristik Wilayah, Prasarana dan Sarana, Sumber Daya Alam, Energi, dan Lingkungan Hidup.

2. Pembangunan: Indeks Pembangunan Manusia (IPM), Indeks Pembangunan Gender (IPG), Capaian MDGs Kabupaten Sleman, Kependudukan (Demografi), Pemberdayaan Masyarakat, Pertanian, Perikanan dan Kehutanan, Kesehatan, Pendidikan

3. Ekonomi : Struktur Perekonomian Daerah, Produk Domestik Regional Bruto (PDRB), Potensi Unggulan Daerah, Lembaga Keuangan, Badan Usaha Milik Daerah (BUMD), Inflasi, Industri, Perdagangan, Koperasi.

4. Sosial Budaya: Kesejahteraan Sosial, Generasi Muda dan Olah Raga, Ketenagakerjaan, Kesenian dan Kebudayaan, Agama, Ketertiban Masyarakat, Politik, Hukum

5. Keuangan Daerah : Keuangan Daerah, Neraca Komparatif, Laporan Realisasi Anggaran , Laporan Arus Kas, Laporan Surplus dan Defisit .

Disamping itu berbagai tampilan informasi di Kabupaten Sleman juga dapat diakses melalui berbagai website maupun juga terbitan berkala seperti yang dapat diakses oleh masyarakat.

Terwujudnya penyelenggaraan negara yang baik, transparan, efektif dan efisien serta akuntabel serta masyarakat mengetahui alasan pengambilan kebijakan yang mempengaruhi hajat hidup orang banyak. Juga meningkatnya pengetahuan dan kecerdasan masyarakat dan atau meningkatnya kualitas pelayanan informasi oleh badan-badan publik. Selain itu terwujudnya penyelenggaraan negara yang baik, transparan, efektif dan efisien serta akuntabel serta masyarakat mengetahui alasan pengambilan kebijakan yang mempengaruhi hajat hidup orang banyak.

Untuk Kabupaten Sleman hal ini oleh Dinas Perhubungan Komunikasi dan Informatika dengan mengacu pada Dasar Hukum:

1. Perda No 9 Tahun 2009 tentang Organisasi Perangkat Daerah Pemerintah Kabupaten Sleman

2. Peraturan Bupati Sleman Nomor 32 Tahun 2009 tentang Uraian Tugas, Fungsi dan Tata Kerja Dinas Perhubungan, Komunikasi dan Informatika Kabupaten Sleman yang dalam hal ini memberikan dukungan teknis dalam penyediaan informasi publik di Pemda Sleman dari proses menghasilkan, penyimpanan, pengelolaan, pengiriman dan atau penerimaan informasi publik oleh Pemda Sleman (Indarto, 2011).

Di era keterbukaan saat ini hal ini bukanlah menjadi kendala jika memang masyarakat berkeinginan untuk mendapatkan berbagai informasi tersebut. Hal ini dapat diakses melalui 
berbagai saluran dan keran keterbukaan informasi yang dapat diakses oleh masyarakat Sleman antara lain melalui:

1. Portal Web Sleman (http://www.slemankab.go.id)

2. Sistem Penanggulangan Kemiskinan (http://pronangkis.slemankab.go.id)

3. Sistem Pelayanan Perizinan Terintegrasi (72 Jenis Perizinan, http://perizinan.slemankab. go.id)

4. Sistem Pelayanan Pengaduan Keluhan dan Saran (http://keluhan.slemankab.go.id)

5. Sistem Informasi Administrasi Kependudukan (SIAK Online)

6. Sistem Pelayanan Catatan Sipil (layanan Akta Kelahiran, Kematian, Perkawinan, dil)

7. Sistem Pendaftaran CPNS Online (http://cpns.slemankab.go.id)

8. Sistem Layanan Pengadaan Secara Elektronik (http:///pse.slemankab.go.id)

9. Sistem Layanan SMS Gateway (http://sms.slemankab.go.id)

Dari paparan di atas maka dapat dikatakan bahwa Sleman telah membuka akses utuk informasi publik tersebut artinya ini adalah sebuah niatan baik dari penyelenggara pemerintahan. Pentingnya meningkatkan kesadaran staf lembaga publik dan masyarakat akan pentingnya informasi dan pemanfaatan informasi. Lembaga publik perlu menyediakan informasi publik yang memadai, namun demikian kegiatan ini akan sulit berjalan efektif jika masyarakat tidak didorong dan dilibatkan dalam pemanfaatan informasi publik yang ada.

Masih menurut Agus Indarto (2011), dalam upaya pengembangan kemitraan penyebarluasan informasi publik, pelayanan informasi publik memerlukan keterlibatan tidak hanya lembaga pemerintah tetapi juga lembaga penyiaran (publik dan swasta), dan lembaga kemasyarakatan yang bergerak dalam bidang komunikasi dan informasi. Pemanfaatan lembaga kemasyarakatan dan berbagai media baik elektronik ataupun media tradisional, media komunitas, dan media kemasyarakatan lainnya akan membantu penyebaran informasi yang tepat dan cepat. Kerja sama dengan pemerintah daerah dan lembaga-lembaga kemasyarakatan di daerah merupakan keniscayaan untuk menciptakan jembatan akses komunikasi yang efektif dan efisien.

Salah satu aspek penting tentang pemerintahan yang di teliti oleh Nurlaili ( 2010 ) dengan instrumen transparansi pengelolaan keuangan daerah ini terbagi ke dalam 3 tahapan, yaitu perencanaandan penganggaran, pelaksanaan, dan pelaporan. Masing-masing tahapan memiliki 5-6 indikator utama yaitu terbuka: akses, jujur, keterlibatan masyarakat, umpan balik, dan tepat waktu. Tahapan perencanaan dan penganggaran dengan rincian indikator berkaitan dengan kegiatan Musyawarah Perencanaan Pembangunan (Musrenbang), penyusunan Rencana Kerja Pemerintah Daerah (RKPD), dan penyusunan Anggaran Pendapatan dan Belanja Daerah (APBD). Tahapan pelaksanaan berkaitan dengan perubahan APBD dan pengadaan barang dan jasa. Tahapan pelaporan berkaitan dengan laporan keuangan, peraturan daerah tentang pertanggungjawaban APBD dan opini Badan Pemeriksa Keuangan (BPK). Pemerintah daerah yang menduduki peringkat pertama dalam transparansi pengelolaan keuangan daerah adalah Kota Yogyakarta dengan presentase nilai 76\%, peringkat kedua Kabupaten Sleman (75\%), peringkat ketiga Kabupaten Kulon Progo (55\%), peringkat keempat Kabupaten Gunungkidul $(42 \%)$, dan peringkat kelima Kabupaten Bantul (34\%).

Capaian keterbukaan KIP di Sleman telah mendapatkan penghargaan Anugerah Media Humas tahun 2012 sebagai juara 2 untuk kategori Laporan Kerja Humas Pemerintah Daerah Provinsi/ Kabupaten dari Badan Koordinasi Kehumasan (Bakohumas). Sedangkan 
Juara I diraih oleh Provinsi Jawa Barat dan Juara III diraih oleh Kabupaten Kutai Kartanegara. Menurut Ketua Penyelenggara Anugrah Media Humas (AMH) yang juga menjabat sebagai Ketua Bakohumas dan Dirjen Informasi Komunikasi Publik (IKP) Kementrian Kominfo Freddy H.Tulung, penganugerahan media humas merupakan salah satu bentuk upaya apresiasi untuk sekaligus merangsang, mendidik dan meningkatkan ketrampilan diseminasi dan kemampuan humas pemerintah sehingga mewujudkan kinerja yangg optimal dalam reformasi kehumasan. Laporan kinerja humas terdapat peningkatan kualitas pengemasan dan juga kegiatan yang dilaksanakan. Penilaian dilakukan pada aspek indikator keterbukaan informasi, penilaian substansi program kehumasan yang dilaksanakan selama tahun 2011, perspektif dan strategi kehumasan yang dikembangkan serta capaian output, sistematika dan pengemasan pelaporan.

Seknas Fitra dalam laporannya juga menempatkan sleman sebagai kabupaten nomor urut 5 dalam keterbukaan anggaran berdasarkan penelitian yang dilakukan pada tahun 2009 . Masih dikutip dari www.slemankab.go.id, Pemkab Sleman baru tahun ini memasukkan laporan kinerja humas pada kegiatan lomba tersebut. Bagi Pernkab Sleman Prestasi tersebut merupakan hasil sinergi semua SKPD, pimpinan dan aparat humas dalam mengimplemetasikan fungsi kehumasan. Namun demikian di sisi lain penghargaan tersebut juga memberikan sebuah tantangan bagi Pemkab Sleman untuk dapat meningkatkan peran yang tidak hanya memberikan informasi, melakukan diseminasi informasi dan penjaringan aspirasi masyarakat tetapi juga mampu mengedukasi publik, sehingga mampu wujudkan kondisi yang kondusif untuk pelaksanaan pembangunan daerah dan peningkatan kesejahteraan masyarakat Sleman.

\section{PENUTUP}

Parameter keberhasilan KIP adalah masyarakat aktif berpartisipasi dalam proses pengambilan kebijakan publik dan masyarakat berperan aktif turut mendorong terwujudnya badan publik yang baik. Selain itu terwujudnya penyelenggaraan negara yang baik, transparan, efektif dan efisien serta akuntabel serta masyarakat mengetahui alasan pengambilan kebijakan yang mempengaruhi hajat hidup orang banyak. Harapannya adalah terjadinya pertemuan antara apa yang diinginkan oleh masyarakat Sleman yang sesuai dengan apa yang dirancang dalam berbagai peraruran perundangan dan kebijakan yang ditetapkan bersama antara legislatif dan eksekutif sebagai bentuk agregasi kepentingan masyarakat Sleman sehingga pertemuan kepentingan dan keterbukaan informasi publjk tersebut akan tercipta masyarakat yang SEMBADA sebenar-benarnya.

\section{DAFTAR PUSTAKA}

Rais, M. Amien (2008) Selamatkan Indonesia, Agenda Mendesak Bangsa. Yogyakarta: PPSK Press.

Bambang Purwoko (2004) "Akuntabilitas Demokratik Dalam Penyelenggaraan Pemerintahan Daerah", dalam Dadang Juliantara (2004) Pembaruan Kabupaten: Arah Realisasi Otonomi Daerah. Yogyakarta: Pembaruan

Endiarto Agoes Soesilo (2011) "Menggagas Keterbukaan Informasi yang Sesungguhnya (Implementasi UU KIP untuk semua Badan Layanan Publik )" Makalah Workshop Ma'arif Institute Sleman

Kasim, Ifdhal (2009) "Kebebasan Memperoleh Informasi dan Rahasia Negara, Makalah Diskusi IDSPS 2009. 
UNISIA, Vol. XXXIII No. 75 Juli 2011

Koalisi untuk Kebijakan Informasi, Kebebasan Informasi di Beberapa Negara. Koalisi untuk Indonesia. www.icel.or.id/transparansi dan partisipasi.com

Fitriyah, Laili (2012) "Pemeringkatan Kadar Transparansi Pengelolaan Keuangan Daerah Pemerintah Kabupaten/Kota Daerah Istimewa Yogyakarta". dalam Jurnal Accounting and Business Information Systems (ABIS). Volume I. No 1. 30

Subadi, Temon (2011) "Siapkah Badan Publik Menghadapi Keterbukaan Informasi Publik?" Asdep Humaslem Persidangan Kabinet dalam http://www.setkab.go.id/artikel-4915-. html, diakses 24 September 2012.

Undang-Undang No 14 Tahun 2008, tentang Keterbukaan Informasi Publik

http: //www.slemankab.go.id

http://seknasfitra.org/wp-content/uploads/2012/10/Kinerja-Pengelolaan-Anggaran-Daerah2009.pdf 